\title{
Politik Penguasaan Teknologi: Jalan Keluar dari Stigmatisasi Negara Berkembang di Regional Asia
}

\section{Bagus Pradana}

\author{
Ifada Initiatives, Yogyakarta
}

\begin{abstract}
INTISARI
Tulisan ini berkeinginan untuk menjelaskan bagaimana stigmatisasi sebagai negara berkembang di regional Asia bisa terjadi dan secara bersamaan menujukkan adanya peluang untuk keluar dari keadaan tersebut. Sebagaimana diketahui bersama, nyaris semua rujukan negara maju adalah negara-negara di Eropa dan Amerika, yang memiliki tingkat kemutahiran terhadap teknologi yang tinggi. Berangkat dari poin tersebut, maka penulis melakukan kajian pustaka untuk melihat bagaimana politik penguasaan teknologi berkembang di Asia. Pengalaman perusahaan Acer dan perusahaan rintisan Gojek, menjadi pelajaran berharga bahwa negara-negara di regional Asia harus mulai keluar dari jebakan komoditas, terutama yang masih berkutat pada industri barang mentah. Dengan politik penguasaan teknologi inilah, sebuah negara bisa duduk sejajar dalam pergaulan global.
\end{abstract}

\section{KATA KUNCI}

Asia; Acer; Gojek; jebakan komoditas; negara berkembang; politik penguasaan teknologi

\section{Pendahuluan}

$\mathrm{T}$

idak dapat dipungkiri bahwa stigma negara dunia ketiga atau negara berkembang (development countries) masih sering disandang oleh negara-negara di regional Asia. Status tersebut semakin meleka erat dibuktikan dengan hasil survei-survei internasional yang dilakukan untuk mengukur pertumbuhan ekonomi hingga pembangunan infrastruktur (Economic and Social Council, 2018). Hasil survai tersebut menyatakan bahwa sebagian besar negara-negara di Asia belum memenuhi standar pembangunan yang layak. Legitimasi status negara dunia ketiga ini bahkan masih diperparah dengan pekerjaan rumah yang belum diselesaikan seperti kesenjangan sosial, kemiskinan, rendahnya kesadaran kesehatan masyarakat, rendahnya tingkat pendidikan, masalah sampah hingga

\section{Korespodensi:}

Ifada Initiatives. Jalan Cepoko Indah, Cepokojajar, Sitimulyo, Kec. Piyungan, Bantul, Daerah Istimewa Yogyakarta 55792.

Email: sentotbaguspradana@gmail.com. 
kepadatan penduduk, semua persoalan itu sangat mengganggu iklim investasi di mayoritas negara Asia.

Merujuk pada survai rutin yang dilakukan oleh United Nations Development Programme Tahun 2018 (UNDP), terkait dengan derajat pembangunan manusia diperoleh hasil bahwa dari 189 negara yang termasuk dalam list survai derajat pembangunan manusia UNDP, mayoritas negara yang menduduki peringkat 100 hingga 189 adalah negara-negara di regional Asia (terutama Asia Tenggara) dan Afrika, diantaranya Filipina (113), Indonesia (116), Vietnam (117), Timor Leste (132), Laos (139), Kamboja (146), dan Myanmar (148). Meskipun terdapat juga negara Asia yang menduduki peringkat tinggi dalam derajat pembangunan manusia, yaitu Hong Kong (7), Singapura (9), Jepang (19), Korea Selatan (23), Brunai Darussalam (39), dan Malaysia (57). Ketimpangan tersebut sangat kontras, dan mungkin berdasarkan survei derajat pembangunan manusia tersebur, ada banyak yang bertanya mengapa di regional Asia ada negara yang memiliki derajat pembangunan manusia yang tinggi, tetapi ada juga negara yang memiliki derajat pembangunan manusia yang rendah? Hal apa yang dilakukan oleh negara-negara Asia yang menduduki peringkat tertinggi UNDP untuk lepas dari stigma negara dunia ketiga yang melekat padanya?

Beragam kajian berkaitan dengan studi pembangunan di regional Asia rutin dilakukan oleh para peneliti dari Asian Development Bank (ADB) terutama pasca krisis ekonomi yang sempat melanda Asia. ADB rutin menerbitkan serial working paper yang ditujukan sebagai masukan ADB kepada negara-negara di Asia untuk menganalisis potensi industri di negaranya agar dapat dioptimalkan dalam rangka pembangunan ekonomi makro. Salah satu working paper ditulis oleh Felipe, Kumar, \& Abdon (2010) yang memberikan ulasan tentang klasifikasi (ranking) pertumbuhan ekonomi makro dari 154 negara di dunia berdasarkan kegiatan ekspor di masing-masing negara. Dari kajian itu bisa dilihat bahwa klasifikasi produk-produk unggulan ekspor apa saja yang memiliki permintaan pasar yang tinggi. Sebagaimana digambarkan, dari 779 komoditas yang masuk daftar ekspor, 352 jenis produk mereka nyatakan sebagai produk dengan kemutahiran tinggi (sophistication) yang potensial untuk dikembangkan dan ramah investasi.

Merujuk pada klasifikasi komoditas tersebut, para peneliti ADB ini kemudian menemukan korelasi antara komoditas andalan di suatu negara dengan pertumbuhan ekonomi di negara tersebut. Kecenderungan yang dimiliki oleh negara-negara kaya (rich countries) adalah sektor industrinya yang didominasi oleh produksi barang-barang dengan tingkat kemutahiran tinggi. Ini artinya, penguasaan teknologi menjadi kunci utama yang membedakan antara negara kaya (rich countries) dan negara berkembang (development countries). Negara-negara kaya memiliki orientasi pada penguasaan teknologi yang mumpuni, sehingga mereka memiliki kesempatan untuk mengembangkan beragam produk dengan tingkat kemutahiran tinggi, mendapatkan kepercayaan pasar atasnya, dan memiliki kontrol atau economics bergaining melalui rantai nilai produksi (supply chain network) dari produkproduk yang mereka hasilkan (Martel \& Klibi, 2016). Beberapa sektor produksi yang memiliki singgungan langsung dengan penguasaan teknologi —dalam pengertian memiliki tingkat kemutahiran tinggi- antara lain elektronik, telekomunikasi, tekstil, kimia dan lain sebagainya. Sementara negaranegara dunia ketiga biasanya hanya menggantungkan ekonomi makronya pada produksi komoditas 
dengan tingkat kemutahiran rendah, biasanya didominasi oleh industri ekstraktif atau industri padat-karya seperti sektor perkebunan, pertanian, dan pertambangan, yang memiliki corak produk raw material (bahan mentah). Bila negara-negara dunia ketiga ini tidak segera merubah orientasi industrinya, maka mereka akan jatuh dalam jebakan komoditas (product trap).

Istilah jebakan komoditas ini digunakan untuk menggambarkan suatu kondisi ketika suatu negara tidak dapat lepas dari ketergantungan untuk memproduksi komoditas dengan tingkat kemutahiran yang rendah (Zysman, 2014). Memang industri ekstraktif lebih menjanjikan daripada industri dengan tingkat kemutahiran tinggi, selain keuntungan lebih cepat diperoleh, pangsa pasarnya juga luas. Namun persaingan ekonomi paling keras justru berada di sektor ini karena kompetitornya sangat banyak, iklim persaingannya pun sangat monopolistik, serta diversifikasi produksi dari produk yang dihasilkan terbatas. Oleh karena itu, pertimbangan kuantitas pada akhirnya yang akan menjadi daya tawar dalam perdagangan komoditas tersebut.

\section{Berkubang dalam Jebakan Komoditas}

Di satu sisi industri hulu yang kebanyakan bercorak ekstraktif (bahan mentah) memang sangat menguntungkan dibandingkan dengan sektor industri lain, terlepas dari beberapa dampak kerusakan lingkungan yang akan ditimbulkannya. Industri bahan mentah adalah industri yang "basah". Oleh karena itu, banyak negara (terutama negara-negara di dunia ketiga) yang mengorientasikan hampir seluruh potensi industrinya untuk sektor ini. Krisis lingkungan akan menjadi ancaman tersendiri bila suatu negara melakukan eksplorasi besar-besaran pada sektor ini. Namun, dalam pendekatan ekonomi politik, ancaman utama yang disinyalir mengancam keberlangsungan industri ini bukan krisis lingkungan, tetapi justru produksi komoditas yang tidak memiliki potensi untuk dikembangkan karena diversifikasnya rendah. Dalam bahasa lain, produk dengan tingkat kemutahiran rendah terjadi karena corak komoditas di sektor tersebut hanya menempati posisi paling bawah dalam proses kreasi nilai tambah (value added). Inilah yang disebut product trap, jebakan yang biasanya menjerat negara-negara dunia ketiga.

Indonesia dan negara-negara di regional Asia Tenggara pernah terjerumus dalam product trap itu-dalam jangka waktu yang relatif lama-ketika "oil boom" terjadi pada tahun 1990-an, inilah zona nyaman dalam ekonomi makro, komoditas yang dihasilkan memiliki harga yang tinggi, dan fresh money datang langsung dari penjualan komoditas raw material-nya (Yi, 2010). Kondisi ini menciptakan delusi ekonomi yang seringkali menghanyutkan negara-negara dalam jeratan product trap. Industri dalam negerinya tidak berkembang, kerusakan lingkungan terjadi di mana-mana, dan yang paling parah adalah mental konsumerisme yang secara tidak sadar mengontrol kehidupan warga negaranya. Negeri yang telah terjatuh dalam kubangan tersebut akhirnya hanya akan diorientasikan sebagai "keranjang sampah" pasar bagi produk-produk mutahir dari negara-negara maju (Goh \& Simon, 2008).

Apabila negara dunia ketiga tidak melakukan diversifikasi produksi, maka secara otomatis negaranegara ini akan berada di urutan rantai industri paling bawah, yang hanya bertugas menyediakan raw material (bahan baku) untuk industri dengan tingkat diversifikasi tinggi yang telah terlebih dahulu 
menguasai pasar dan teknologi produksi. Kesempatan yang sangat kecil untuk lepas dari lingkaran setan industri bahan mentah banyak membuat negara-negara dunia ketiga memilih untuk tetap hanyut dalam jebakan komoditas dengan kemutahiran produksi rendah.

Kajian sebelumnya mengenai kemutahiran produksi ini pernah dilakukan oleh Hidalgo, Klinger, Barabási, \& Hausmann (2007). Meskipun dalam kajian tersebut tidak sampai melakukan pemetaan mengenai corak produksi di tiap negara, namun bisa dikatakan bahwa kajian ini merupakan salah satu kajian awal berkaitan dengan diversifikasi produksi, terutama analisis potensi ekonomi dari produkproduk yang memiliki tingkat kemutahiran tinggi. Hidalgo dkk., (2007) menyatakan bahwa sejumlah komparasi ekonomi yang mengerangkai narasi tentang penerimaan pasar ekspor terhadap produkproduk yang memiliki tingkat kemutahiran tinggi, bukan produk-produk yang masih berbentuk raw material yang tingkat pengembangannya rendah, seperti komoditas pertanian, pangan, dan pertambangan.

Selanjutnya, pada tahap ini, istilah product space atau derajat kemutahiran dari suatu produk mulai diperkenalkan. Derajat kemutahiran ini ditentukan oleh network value (rangkaian nilai tambah yang terkandung dalam satu produk) misalnya: Smartphone, material apa saja yang ada dalam smartphone bila diperinci secara detail? Di sana terdapat: plastik, mineral aktif, besi, timbal, kaca, dan lainnya yang nilai produksi sebenarnya berkali lipat lebih rendah daripada nilai jualnya. Semakin banyak network value dari komponen material yang terdapat dalam satu produk maka semakin tinggi derajat kemutahiran produksi (product space) dari suatu produk.

Berangkat dari kajian yang dilakukan Felipe dkk. (2010) maupun Hidalgo dkk. (2007), terlihat bahwa telah terjadi suatu proses hegemoni yang terdapat dalam sektor Industri, terutama yang secara jelas terpampang dalam produk hasil akhir dari suatu proses produksi yang beredar di pasaran. Apabila dalam kajian sosial-politik hegemoni itu sangat sublim, maka lain halnya dengan kajian ekonomi yang tergambar nyata dalam produk. Tingkat kemutahiran suatu produk bisa diuraikan secara detail dengan melihat proses produksi dari setiap jaringan produksi yang sangat luas, yang terhubung satu sama lainnya. Hal ini semua dihubungkan oleh satu prinsip ekonomi modern, yaitu: Inovasi.

Salah satu prasyarat utama dalam inovasi ekonomi adalah penguasaan teknologi. Adapun teknologi sendiri saat telah menjadi sumberdaya kuasa baru, dimana keberadaannya merupakan kunci utama dari proses produksi suatu komoditas. Tidak mengherankan jika kemudian teknologi sering dikaitkan dengan minat/ kecenderungan pasar, yakni siapa yang mampu menguasai teknologi maka mereka yang akan menguasai pasar. Dari sini, teknologi telah menjadi kunci utama dari keberhasilan industrialisasi.

Bila kita baca teknologi sebagai salah satu instrumen kuasa (power) dalam konteks relasi ekonomi antar negara, maka hukum yang berlaku adalah jika suatu negara memiliki teknologi, maka negara itu akan mampu menciptakan hubungan kuasa dengan negara-negara lainnya yang menjadi konsumen (pengguna) dari produk-produk teknologi yang dihasilkan oleh negara tersebut. Namun, jika suatu negara hanya memiliki modal atau sumberdaya kapital saja, maka belum tentu negara tersebut akan dapat melakukan penguasaan teknologi (Majumdar, Guha, \& Marakkath, 2015). 
Hal ini menjelaskan mengapa terdapat satu corak kesamaan yang dialami oleh negara-negara yang memiliki sumberdaya kapital besar seperti Qatar, Arab Saudi, dan Uni Emirate Arab, tetapi tidak dapat melakukan penguasaan teknologi? Apabila kita berpatokan pada hukum diversifikasi produksi seperti yang telah dibahas sebelumnya, maka negara-negara ini hampir kesemuanya memiliki fokus industri dengan tingkat diversifikasi yang rendah. Hal ini ditunjukkan oleh kecenderungan fokus industrialisasi yang merela lakukan, diantaranya pertambangan dan migas. Namun karena mereka memproduksi raw material yang sudah pasti dicari oleh banyak negara, mereka akhirnya dapat dengan cepat mengakumulasi kapital dengan segala resikonya di masa depan.

Dalam prinsip inovasi, teknologi menjadi salah satu fondasi dasarnya. Teknologi adalah instrumen hegemoni yang mampu menciptakan jaring-jaring penghubung dalam proses produksi suatu barang dengan tangkat kemutahiran tinggi. Bentang luas jaring produksi dari suatu barang ini akan menggambarkan irisan-irisan keterhubungan antar satu sektor dengan sektor lainnya. Semakin mutahir barang yang diproduksi, maka bentang jaringannya akan semakin luas (Mann \& Chan, 2011). Hal ini bisa dijelaskan sebagaimana gambar di bawah ini.

Gambar 5: Derajat Kemutahiran Produk

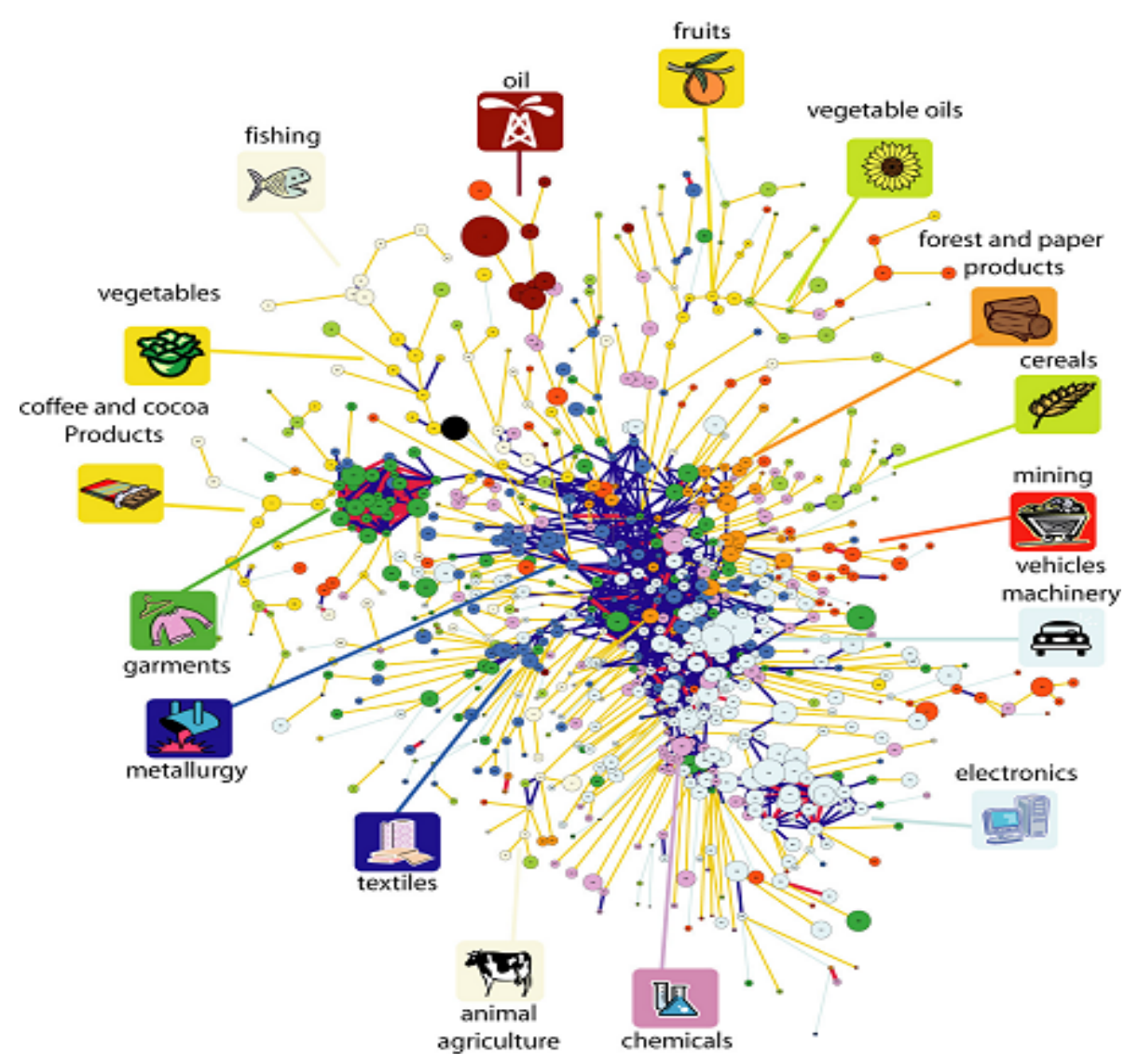

Sumber: Hidalgo dkk. (2007) 
Gambar 5 di atas merupakan peta mengenai derajat kemutahiran produk (product space) yang disusun berdasarkan listing/ pendaftaran atas beberapa produk dari mulai yang memiliki diversifikasi rendah, seperti komoditas pertanian, perkebunan, pertambangan, migas, dan lain, dan produk dengan diversifikasi tinggi, seperti industri kimia dan farmasi, manufaktur, komputer, telekomunikasi, transportasi, dan lain sebagainya. Jika merujuk pada gambar tersebut, tiap-tiap sektor ternyata memiliki keterhubungan yang dapat dirunut dengan jelas irisan-irisannya. Produk yang dipenuhi oleh irisan produksi merupakan produk dengan tingkat kemutahiran tinggi. Sementara produk dengan sedikit irisan atau yang berada dipinggiran merupakan produk dengan tingkat kemutahiran rendah.

Pada sektor yang dipenuhi oleh irisan produksi, dapat diinterpretasikan sebagai adanya iklim yang mendukung untuk dilakukan inovasi teknologi. Teknologi akan berkembang pesat pada sektor yang memiliki iklim produksi yang kompetitif. Sebagai salah satu instrumen kuasa (power), teknologi adalah pencipta hubungan kuasa (patron-client) yang sangat baik, yakni pemilik teknologi dapat menciptakan hubungan ketergantungan yang sportif dengan klien atau pengguna produkproduk teknologi. Semakin baik produk dan layakan yang diberikan, maka kepercayaan pengguna atau konsumen akan semakin bertambah. Teknologi adalah lapangan pertempuran yang masih sangat kompetitif, tidak ada aturan baku, yang ada hanyalah pembaharuan dan pengembangan ide semaksimal mungkin. Siapa yang menguasainya terlebih dahulu, maka mereka adalah pemenangnya.

Meskipun demikian, menguasai teknologi bukanlah perkara mudah bagi suatu negara. Perez (2001) menunjukkan bahwa dalam siklus hidup teknologi sangatlah bergantung dengan perkembangan teknologi lainnya yang menjadi kompetitornya. Dengan adanya persaingan, maka inovasi akan terjadi dan berbagai macam perbaikan akan dilaksanakan oleh para pengembang. Adapun fase perkembangan dari teknologi itu bisa dijelaskan dari grafik di bawah ini.

Gambar 6: Grafik Fase Perkembangan Teknologi

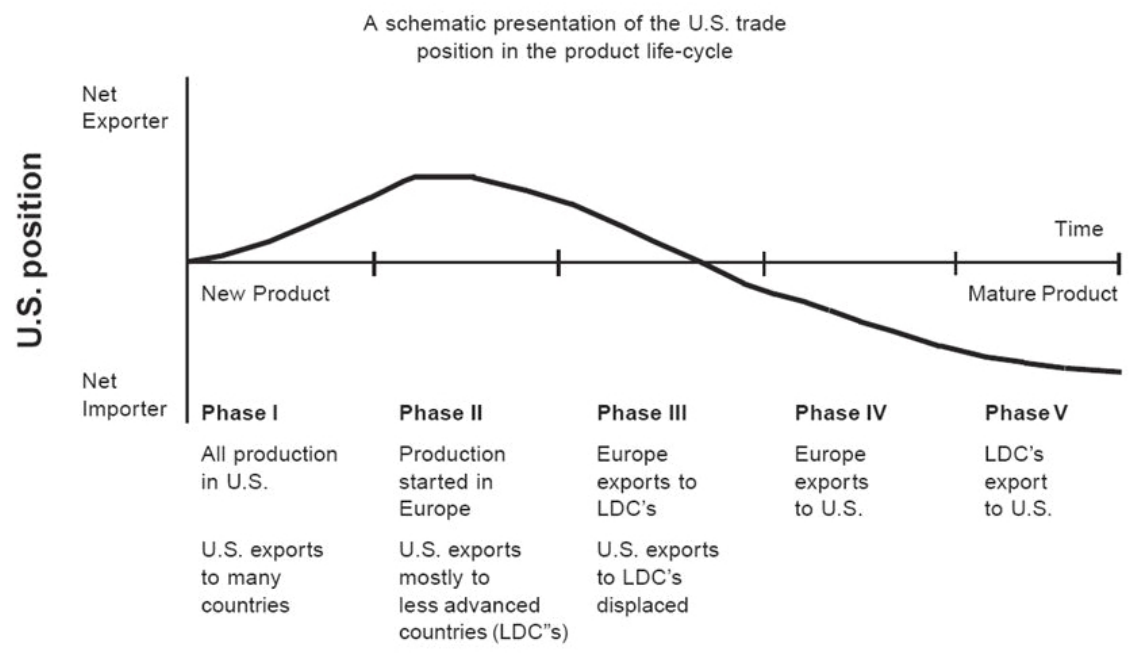

Sumber: Dikutip dari Perez (2001) 
Merujuk pada studi kasus di Amerika Serikat, Perez (2001) menyatakan ada lima fase ketika suatu produk dengan teknologi tinggi dijual di pasaran. Fase pertama adalah fase pengenalan (introduction). Di fase ini, produk ditemukan dan dikenalkan kepada pasar untuk menciptakan ketertarikan dan pangsa pasar yang baru. Fase kedua disebut sebagai fase early growth, yakni ketika pangsa pasar mulai terbentuk, dan momentum peningkatan permintaan kepada produk muncul secara signifikan di fase ini. Fase ini juga menjadi fase akselerasi produksi yang dilakukan produsen untuk memenuhi permintaan pasar. Fase ketiga disebut sebagai fase late growth, di mana titik kulminasi terjadi dalam fase ini. Dalam fase ini terjadi penurunan pangsa pasar karena produk teknologi ini telah tersebar luas, yang menjadikan kebosanan pasar dan penurunan minat beli. Apabila tidak segera direspon oleh produsen maka permintaan terhadap produk akan turun secara drastis.

Selanjutnya, fase keempat disebut sebagai fase maturity, atau fase emas dari suatu produk/ teknologi. Pada fase ini, produk sudah tidak menjadi trand lagi, entah karena telah tergantikan dengan produk baru yang lebih inovatif atau karena faktor lain. Pada fase ini, produsen akan mulai merasakan pembengkakan pengeluaran dan jika tidak segera diatasi dengan membuka resiko kebangkrutan. Di fase inilah biasanya transfer teknologi dilakukan, terutama transfer teknologi ke negara berkembang. Jika negara berkembang mendapatkan transfer teknologi dari para produsen produk-produk termutahir dari negara maju, maka bisa masuk fase berikutnya, yakni fase kelima. Fase ini disebut sebagai fase lanjutan, di mana negara-negara berkembang yang telah menguasai teknologi dan mampu membuat produk mereka sendiri akan mengekspor produk ke negara maju.

Gambar 7: Grafik Proses transfer tekhnolog ke negara berkembang

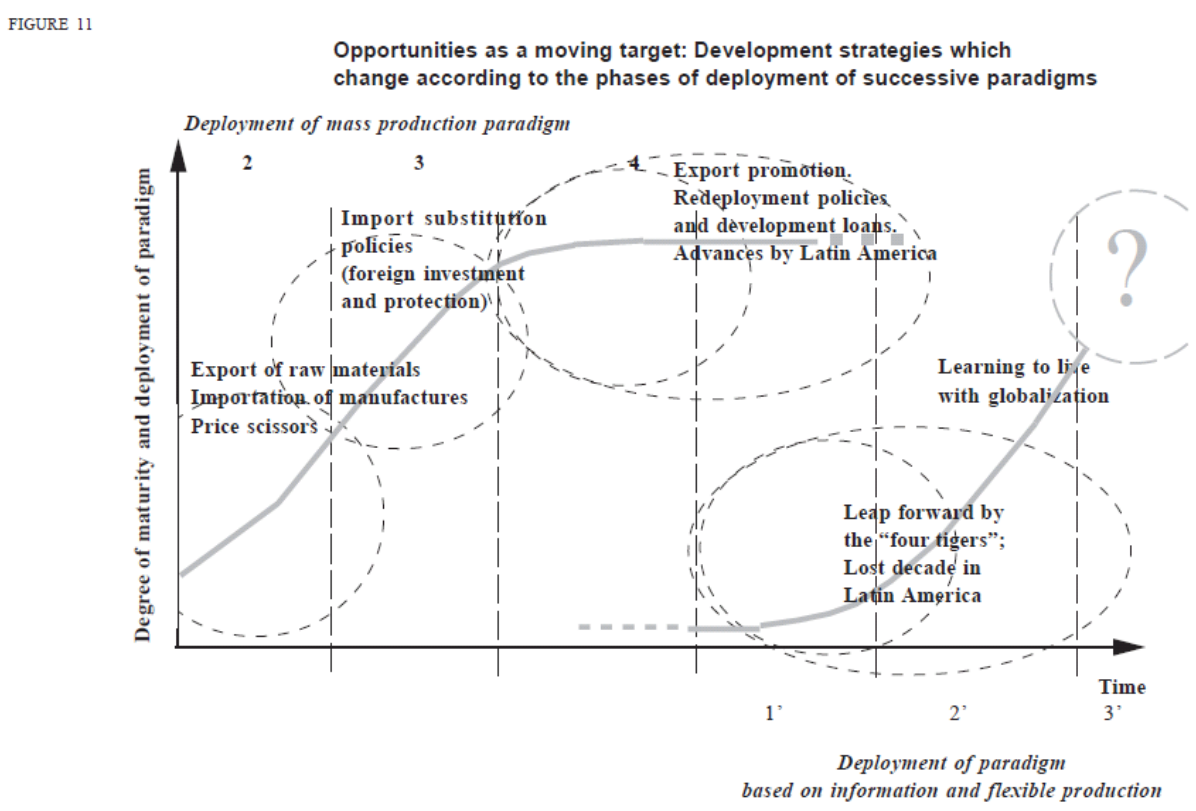

Sumber: Dikutip dari Perez (2001) 
Teknologi memang memiliki pengaruh dominan dalam sektor ekonomi belakangan ini. Teknologi telah menciptakan hukum alam baru yang sulit ditembus oleh negara-negara dunia ketiga yang awam terhadapnya (Mann \& Chan, 2011). Namun, apakah ketertinggalan teknologi ini tidak bisa dikejar? Pengalaman beberapa perusahaan di Asia dalam mengakali hukum teknologi yang sempat dipercayai negara-negara maju ini menjadi sebuah pembelajaran menarik untuk dikaji. Sebuah kasus menarik berkaitan dengan penguasaan teknologi yang terbaru adalah kasus tentang smartphone dan berbagai pengembangannya. Kasus menarik adalah ketika jaringan 3G diupgrade menjadi 4G LTE, produk-produk smartphone pabrikan kelas dua dari Asia mampu membaca sebagai segmen baru yang dapat dikembangkan dengan inovasi-inovasi baru. Untuk itu, mereka melakukan ekspansi pasar untuk menggantikan smartphone yang dulu dikuasi oleh pabrik-pabrik besar Eropa-Amerika seperti Siemens, Nokia, Blackberry dan lain sebagainya.

Pabrik-pabrik di Asia ini kemudian mengembangkan produk-produk smartphone dengan fiture yang tidak kalah modern dari smartphone pabrikan brand-brand besar Eropa. Mereka mengedepankan fasilitas-fasilitas layanan sederhana seperti sosial-media, game, dual sim-card hingga aplikasi camera portabel yang memang menjadi kebutuhan pasar di Asia pada waktu itu dan belum dibaca oleh smartphone pabrikan Eropa-Amerika. Dalam perjalanannya, ternyata smartphone pabrikan di Asia berhasil mengalahkan pabrikan Eropa-Amerika. Konsumen lebih memilih smartphone produksi Samsung, Asus, Xiaomi, Acer, dan lain sebagainya, yang dulu menjadi produk nomor dua dalam pasar smartphone.

Jika dirunut, pangkalnya ternyata ada pada masalah kapabilitas sosial (social capabilities), bahwa teknologi hidup dalam seting sosial tertentu. Di mana saat ini kebutuhan orang-orang di Asia bukan pada kesempatan menikmati layanan akses terpadu, yang mampu menjamin privasi dan sekuritasnya seperti layanan yang dikeluarkan pabrik-pabrik smartphone Eropa-Amerika kala itu, tetapi hanya sebatas jaringan super cepat ala 4G LTE (yang kini akan berkembang menjadi 5G-lte) untuk kebutuhan sosial mereka yang baru, yaitu berkomunikasi via Media Sosial.

Ketika kapabilitas sosial yang ada baru sampai penggunaan media-media sosial, aplikasi gaming, dan kualitas kamera di Smartphone yang bagus, maka ketika itu pula produk dengan harga terjangkau dan fasilitas penunjang yang lengkap yang akan dipilih oleh konsumen. Inilah yang disebut "rejuvenasi" atau kemampuan bangkit dengan memanfaatkan pertimbangan-pertimbangan kapabilitas yang dapat digunakan disekitarnya. Produk-produk smartphone pabrikan asal Asia kini pun berhasil membuktikan bahwa mereka dapat mengembalikan kehormatannya dalam perekonomian global.

\section{Jalan Keluar: Belajar dari Kisah Sukses Para Naga}

Naga dalam mitologi timur adalah suatu makhluk yang menyerupai ular, bertanduk, dan berkaki, serta dapat menyemburkan lidah api. Dalam budaya timur, naga adalah simbol atau perlambang dari kebijaksanaan, keberanian dan kemajuan. Simbolisasi Naga inilah yang dipakai oleh Mathew (2002) dalam bukunya untuk menggambarkan kebangkitan dari negara-negara Asia yang berhasil mematahkan hukum keterlambatan, yang sering melekatkan stigma pada mereka sebagai pihak kalah dalam persaingan industri global. ${ }^{1}$ Stigma tersebut ternyata berhasil dimentahkan oleh negara-negara 
seperti Taiwan, China, Korea selatan dan Jepang. Mereka membuktikan bahwa mereka mampu hadir dalam persaingan industri dan ekonomi global. Bukan hanya hadir, mereka juga telah diakui oleh negara-negara maju, sebagai rival bisnis atau pesaing yang sepadan. Brand seperti Toyota, Mitsubishi, Yamaha, Honda, Hyundai, KIA, Samsung, Panasonic, Compact, Acer, ASUS, Xio-Me, Huawei dan Tiens adalah beberapa perusahaan Multinasional yang dimiliki oleh negara-negara di region Asia. Mereka memiliki perjalanan yang panjang hingga mampu melakukan pencapaian seperti sekarang ini.

Salah satu contohnya adalah Acer, perusahaan IT multinasional dari Taiwan (Indochina) merupakan generasi perusahaan bidang Informasi dan Telekomunikasi (IT) pertama di Asia yang berdiri pada tahun 1990. Tetapi kini Acer menjadi salah satu brand rujukan ternama dalam pasar gadget dan IT internasional. ${ }^{2}$ Taiwan sendiri adalah salah satu negara di region Asia yang terhitung jeli menangkap peluang ekonomi. Di masa ketika negeri-negeri regional Asia lain diliputi keberlimpahan kapital karena Bom Minyak di tahun 1990-an, Taiwan tidak serta merta tergiur untuk melakukan konsentrasi industri di sektor migas saja, tetapi justru mengeluarkan kebijakan untuk melakukan pembangunan sentra-sentra industri terutama dalam bidang elektronika dan IT. Produk-produk seperti televisi, radio, komputer, dan laptop adalah produk yang menjadi komoditas utama Acer saat itu. Acer menjadi salah satu perusahaan bidang IT yang dimiliki oleh Taiwan yang akhirnya berhasil menembus pasar internasional dengan produk-produk IT-nya seperti laptop dan perangkat-perangkat komputer yang mampu mengimbangi produk-produk lain dari Eropa-Amerika seperti Apple, HP, Seamens, dan lain sebagainya.

Awalnya Acer adalah perusahaan kecil yang didirikan oleh seorang pengusaha IT bernama Stan Shih di sebuah kamp / daerah sentra industri di Taiwan. Sebagai perusahaan baru tantangan terbesar Acer pada masa itu adalah memperoleh pasar untuk barang-barang produksinya. Tetapi karena pesaing-pesaingnya di bidang IT adalah perusahaan-perusahaan besar Eropa yang telah unggul di pasar terlebih dahulu, Acer yang dipimpin Stan Shih sadar bahwa perusahaannya tidak akan mampu bersaing dengan brand-brand besar tersebut. Bagi perusahaannya sangat sulit untuk mendapatkan celah dalam persaingan pasar di bidang IT.

Kesadaran Acer akan posisi sub-ordinan ini kemudian mendorong Shih untuk berfikir dan bertindak melawan teori yang menyebutkan bahwa negara dunia ketiga hanya akan menjadi pihak yang selalu kalah dalam ekonomi. Setelah menimbang dan berfikir sejenak, Shih kemudian memutuskan untuk mengarahkan perusahaannya agar lebih kompromis terhadap kenyataan pasar, -baginya pasar tidak hanya dicari dan diperebutkan tetapi bisa juga diciptakan- maka Acer berusaha menciptakan pasarnya sendiri dari nol. Kebijakan yang diambil Shih adalah mengarahkan Acer untuk melakukan diversifikasi produksi. Produksi yang dilakukan Acer kemudian lebih spesifik pada produksi komponen IT (khususnya untuk PC) seperti CD-ROOM, Harddisk, Motherboard, Chips, monitor dan lain sebagainya. Shih tidak mau mengarahkan Acer langsung bersaing dalam produksi IT skala besar seperti laptop dan berbagai pernak-pernik gadget secara utuh.

Diversifikasi produski yang dilakukan Acer ternyata terbukti berhasil, pertama karena belum ada Brand IT manapun pada waktu itu yang bergerak di industri hilir, yang secara spesifik memroduksi komponen setengah jadi untuk mendukung produk IT utuh seperti laptop atau PC. Kedua jalan 
baru yang ditempuh Acer ini membuatnya memiliki posisi tawar dalam bidang IT sebagai produsen komponen pendukung IT, seperti CD-ROOM, Harddisk, Motherboard, VGA dan perangkat lainnya yang patut diperhitungkan dalam industri IT.

Banyak produk-produk IT yang memproduksi built-up utuh PC atau laptop kemudian melirik produk-produk komponen pendukung yang diproduksi oleh Acer untuk dimasukan ke dalam produk PC atau laptopnya. Karena pertimbangan kualitas dan pengembangan teknologi yang diperkirakan lebih unggul sebagai komponen pendukung, seperti CD-ROOM, Harddisk, Motherboard, VGA daripada yang dimiliki oleh produknya sendiri, maka tidak jarang dalam sebuah Laptop yang bermerk HP, Apple atau lainnya terdapat komponen dengan merk Acer seperti hardisk, VGA atau CDROOM mereka. Dari sana, Acer mulai mendapatkan dominasi pasarnya dan mulai menciptakan ketergantungan pasar melalui inovasi-inovasi pengembangan produknya.

Acer dengan diversifikasi produksinya mampu menembus dinding persaingan industri bidang IT yang bisa dikatakan memiliki tingkat kemutahiran tinggi. Acer bahkan mampu menciptakan ketergantungan pasar terhadap produknya yang spesifik pada komponen pendukung IT, bahkan produk-produk IT seperti HP, Toshiba, Apple telah menjadi pelanggan untuk produk komponenspesifik IT dari Acer agar mampu menyempurnakan kualitas produknya. Ketergantungan inilah yang kemudian menjadi jalan masuk transfer teknologi dari brand-brand besar tersebut kepada Acer. Transfer tersebut dimulai dari kebutuhan terhadap produk Acer, yang akhirnya memaksa mereka membuka rahasia-rahasia produknya kepada Acer karena jika tidak Acer sebagai produsen spesialis komponen pendukung tidak bisa memenuhi permintaan dari kliennya tersebut.

Transfer teknologi cepat atau lambat akan terjadi dalam hubungan saling indusitrial ini. Sebab, setiap aktor yang terlibat dalam hubungan tersebut memegang kendali satu sama lain sehingga transfer teknologi adalah kemutlakan yang pasti akan terjadi, dan Acer mendapatkan itu. Seperti dugaan Shih, Acer pun kemudian merambah pada produksi laptop built up utuh, dan minat pasar terhadap produknya pun tidak kalah tinggi dari brand-brand besar yang telah terlebih dahulu melakukan dominasi di bidang IT. Acer adalah satu prototype Naga multinasional yang dimiliki Asia, dan berhasil besar dengan strateginya sendiri.

\section{Penutup: Bagaimana dengan Indonesia?}

Saat ini, Acer bukan satu-satunya perusahaan Asia yang memiliki pangsa pasar besar di perdagangan global. Ada beberapa perusahaan lain, yang memiliki tingkat valuasi dan ekspansi besar di pasar dunia, tidak terkecuali di Asia Tenggara. Bangkitnya ekonomi Asia Tenggara, yang oleh beberapa kalangan disebut sebagai miracle of Asia (Stiglitz \& Yusuf, 2001), tidak lepas dari tumbuhnya para perusahaan yang penuh dengan inovasi. Salah satu perusahaan itu adalah Gojek, yang merupakan multinational corporation asal Indonesia.

Arus mobilitas baik barang (komoditas) maupun orang (tenaga kerja) merupakan prasyarat utama kegiatan ekonomi berlangsung. Produk harus didistribusikan ke pasar agar roda ekonomi berjalan, para pekerja pun harus difasilitasi agar sampai ke tempat mereka bekerja dengan selamat dan tepat waktu. Dilansir dari data BPS per Februari 2018, jumlah angkatan kerja di Indonesia 
mengalami peningkatan sebanyak 133,94 juta orang, naik 2,39 juta orang dibanding dengan tahun lalu. Peningkatan angkatan kerja tersebut menjadi tantangan tersendiri bukan hanya bagi pemerintah, namun juga bagi para anak-anak muda untuk selalu berinovasi. Pada titik ini potensi tersebut dilirik oleh salah satu platform Start-Up generasi awal di Indonesia yang dikenal dengan sebutan Gojek. Perusahaan ini didirikan pada 12 Oktober 2010 oleh Nadiem Makarim, Kevin Luwi dan Michaelangelo Moran di Jakarta. Mengusung platform digital dalam layanan di bidang transportasi, Gojek berhasil mendapatkan apresiasi publik di Indonesia. Selain itu, terobosan yang Gojek lakukan hingga kini menjadi satu alternatif untuk mengatasi masalah transportasi dan masalah lapangan pekerjaan di Indonesia.

Gambar 8: Grafik Perjalanan Bisnis Gojek

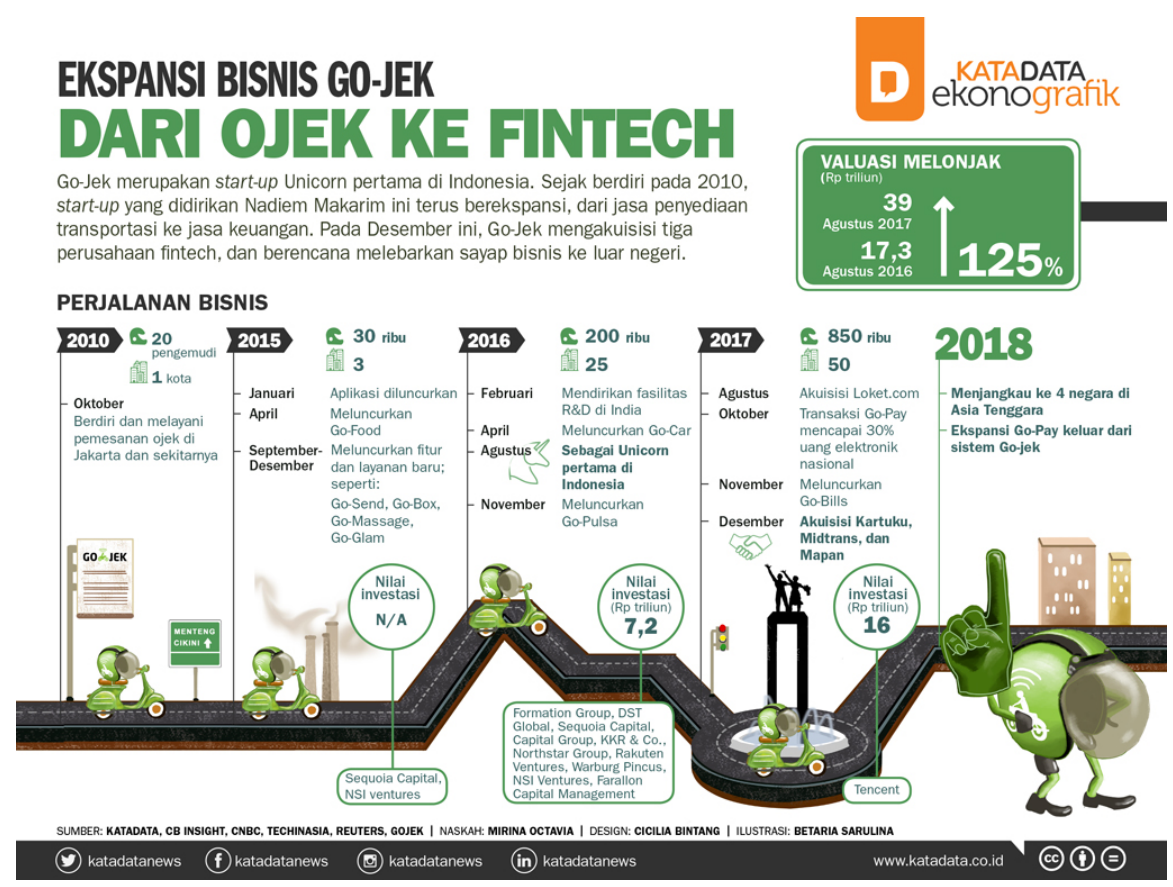

Sumber: Dikutip dari Octavia (2017), Katadata.co.id

Pada awal kemunculannya, banyak yang tidak bersimpati dengan Gojek, bahkan pemerintah pun sempat tidak melirik Gojek sebagai pemain penting dalam bisnis e-Commerce di Indonesia yang pada waktu itu juga masih diraba-raba oleh pemerintah. Gojek bahkan pernah dipandang sebagai failed project karena justru menciptakan segregasi sosial, antara moda transportasi berbayar "Ojek konvensional” dengan "Ojek Online”. Akibatnya pemerintah harus turun tangan untuk mengeluarkan aturan mengenai transportasi online. Namun, dalam waktu yang relatif singkat, Gojek berhasil membuktikan dirinya, visi awal untuk mengatasi masalah transportasi sekaligus masalah pengangguran berhasil mereka realisasikan melalui prinsip ecosystem services yang mereka terapkan, termasuk sistem mekanisme rekrutmen karyawan (driver) yang mereka kembangkan juga inovatif. 
Setiap orang dapat menjadi driver, dan dapat pula menjadi penumpang. Bagi Gojek, Driver adalah "mitra-kerja" yang memiliki hak (gaji) dan kewajiban kerja yang setara dan terjamin.

Di awal kemunculannya, event rekrutmen driver Gojek selalu menyita perhatian karena hampir pasti dipenuhi oleh pelamar yang tertarik dengan tawaran pekerjaan yang ditawarkan oleh Gojek. Fasilitas yang ditawarkan Gojek pun terhitung inovatif sebagai sebuah perusahaan start-up, dimulai dari segmen yang perusahaan ini ambil yaitu pada bidang transportasi publik. Gojek berhasil membaca peluang yang jarang dibaca oleh banyak orang. Gojek juga berhasil mengawinkan prinsip-prinsip dalam teknologi komunikasi dengan sektor transportasi dan ekonomi. Dimulai dari layanan jasa ride hailing dan delivery makanan, Gojek pun instens mengembangkan layanannya ke sektor yang lain dalam jangka waktu 5 tahun Gojek berhasil melakukan ekspansi layanan merambah pada penyediaan jasa lainnya mulai dari ekspedisi pengiriman barang, jasa Taxi, antar jemput sekolah, jasa cleaning service, bahkan kini merambah ke sektor e-commerce dan fintech. Aplikasinya kini telah di download oleh 50 juta pengguna dan telah merambah hingga ke empat negara yaitu Vietnam, Thailand, Singapura, dan Filipina dengan total investasi sebesar US\$ 500 Juta (CNN Indonesia, 2017).

Sebelumnya, ide mengenai platform tranportasi berbasis daring ini pernah dikembangkan untuk pertama kalinya di Amerika oleh Travis Kalanick dan Garrett Camp pada tahun 2009, yakni perusahaan dengan nama Uber. Diilhami oleh keberhasilan Uber di Amerika ini, maka platform sejenis mulai berkembang diberbagai belahan dunia, antara lain Grab di Singapura, Didi di China, dan Gojek di Indonesia dengan berbagai varian layanan inovatifnya.

Keberhasilan Gojek untuk mengembangkan diri melalui mekanisme membaca peluang di masyarakat dan menjembataninya dengan teknologi adalah satu langkah alternative yang berdampak besar. Pelan namun pasti, banyaknya inovasi yang muncul di Indonesia menjadikan ancaman product trap dari hari ke hari semakin dapat diatasi oleh ide-ide pengembangan produk baru yang mampu merubah orientasi ekonomi makro bangsa ini agar merambah pasar yang baru dan tidak hanya berfokus pada produksi komoditas dengan tingkat kemutahiran yang rendah saja.

\section{Ucapan Terima Kasih}

Terima kasih kepada direktur Ifada Initiatives, Irfan Afifi, serta kepada Danang Wahyuono, dan Fuad Khabibi Setiawan atas diskusinya yang berharga selama riset dan penulisan jurnal.

\section{Pendanaan}

Penulis tidak menerima bantuan pembiayaan untuk penelitian, kepenulisan (authorship), dan publikasi dari pihak manapun.

\section{Catatan}

1 Perlambangan Naga untuk negara-negara late-comer di regional Asia dipilih karena dalam budaya Timur, Naga adalah makhluk yang melambangkan kemajuan. Berbeda dengan budaya Barat, Naga dalam mitologi Romawi atau Yunani Kuno adalah perlambangan dari kejahatan. Naga di 
tradisi Barat hampir sama sosoknya dengan Naga timur, yang membedakan adalah Naga di Barat biasanya memiliki sayap dan dapat menyemburkan api yang mampu merubah manusia menjadi batu. Dalam cerita kebudayaan Barat, Naga biasanya akan dikalahkan oleh satria.

2 Kisah mengenai perjalanan Acer dari Taiwan ini diulas dalam bab 1 buku Dragons Multinational a New Models for Global Growth.

\section{Daftar Pustaka}

CNN Indonesia. (2017). Gojek Bersiap Ekspansi ke Empat Negara Asia Tenggara. Diakses pada 19 Agustus 2018, dari https://www.cnnindonesia.com/teknologi/20171002162314-206-245599/ gojek-bersiap-ekspansi-ke-empat-negara-asia-tenggara

Economic and Social Council. (2018). Summary of the Economic and Social Survey of Asia and the Pacific 2018. United Nations. Diunduh dari http://www.regionalcommissions.org/ESCAPsurv18. pdf

Felipe, J., Kumar, U., \& Abdon, A. (2010). How rich countries became rich and why poor countries remain poor: It's the economic structure...duh! Japan and the World Economy, 29, 46-58. https:// doi.org/10.1016/j.japwor.2013.11.004

Goh, E., \& Simon, S. W. (Eds.). (2008). China, the United States, and Southeast Asia: Contending Perspectives on Politics, Security, and Economics. New York: Routledge.

Hidalgo, C. A., Klinger, B., Barabási, A.-L., \& Hausmann, R. (2007). The Product Space Conditions the Development of Nations. American Association for the Advancement of Science, 217(587), 482-487. https://doi.org/10.1126/science.1144581

Majumdar, S., Guha, S., \& Marakkath, N. (Eds.). (2015). Technology and Innovation for Social Change. Springer.

Mann, L., \& Chan, J. (Eds.). (2011). Creativity and innovation in business and beyond: Social science perspectives and policy implications. New York: Routledge. https://doi.org/10.4324/9780203833063

Martel, A., \& Klibi, W. (2016). Designing Value-Creating Supply Chain Networks. Cham: Springer.

Mathew, J. A. (2002). Dragons Multinational a New Models for Global Growth. Oxford: Univercity Press.

Octavia, M. (2017). Ekspansi Bisnis Go-Jek, dari Ojek ke Fintech. Diakses pada 11 Agustus 2018, dari https://katadata.co.id/infografik/2017/12/29/ekspansi-bisnis-go-jek-dari-ojek-ke-fintech

Perez, C. (2001). Technological Change and Opportunities for Developments as a Moving Targe. Cheltenham: Cepal Review.

Stiglitz, J. E., \& Yusuf, S. (Eds.). (2001). Rethinking the East Asian Miracle. World Bank Publications. United Nations Development Programme. (2018). Human Development Indices and Indicator: 2018 Statistical Update. New York: UNDP. Diunduh dari http://hdr.undp.org/sites/default/files/2018_ human_development_statistical_update.pdf

Yi, T. (2010). The Oil and Gas Service Industry in Asia: A Comparison of Business Strategies. New York: Palgrave Macmillan. 
Zysman, J. (2014). Escaping the Commodity Trap: Toward Sustainable Growth. Dalam the BRIE-ETLA Conference on August 29. Diunduh dari https://www.etla.fi/wp-content/uploads/BRIE-ETLA29-Aug-2014-Position-Paper.pdf

\section{Tentang Penulis}

Bagus Pradana adalah alumnus Sarjana Ilmu Pemerintahan, Universitas Gadjah Mada, saat ini berkecimpung sebagai peneliti di Ifada Initiatives, Yogyakarta. 